\title{
Migracja i inwazyjność komórek nowotworowych; rola plastyczności komórek i udział macierzy zewnątrzkomórkowej w tworzeniu przerzutów
}

\author{
Anna Balcerak, Maciej Wakuła, Alicja Trębińska, Ewa A. Grzybowska
}

Zdolność komórek do migracji jest determinowana przez rodzaj tkanki, z jakiej się wywodzą. W przypadku komórek nowotworowych możliwa jest jednak pewna plastyczność fenotypu, umożliwiająca zmianę typu migracji. Zmiany te mogą mieć wpływ na poziom inwazyjności nowotworu. Opisywane procesy pozostają w ścisłej zależności od mikrośrodowiska, w jakim znajdują się komórki i mogą być regulowane przez zmiany zachodzące w macierzy zewnątrzkomórkowej, która w dynamiczny sposób wpływa na potencjał migracyjny i inwazyjny.

\section{Tumour cell migration and invasion: an impact of cell plasticity and extracellular matrix on metastasis}

Migratory and invasive potential of the cell is determined by the type of a tissue from which the cell derives. However, in case of neoplastic cells they display some plasticity of a phenotype which enables changes in the mode of migration. These transitions may influence the metastatic potential of the tumour. Processes described vitally depend on the tumour microenvironment and may be regulated by the dynamic of the extracellular matrix alterations.

NOWOTWORY Journal of Oncology 2016; 66, 1:45-52

Słowa kluczowe: migracja, inwazyjność, przerzut nowotworowy, przejście epitelialno-mezenchymalne, macierz zewnątrzkomórkowa

Key words: migration, invasion, metastasis, epithelial-mesenchymal transition, extracellular matrix

\section{Wstęp}

Poznanie mechanizmów migracji i inwazji jest kluczowe dla zrozumienia zjawiska tworzenia się przerzutu nowotworowego. Regulacja tych procesów jest bardzo złożona i opiera się na skomplikowanej sieci zależności pomiędzy komórkami guza, macierzą zewnątrzkomórkową i towarzyszącymi komórkami prawidłowymi. Zdolność do migracji i w pewnym stopniu z nią związana inwazyjność komórek nowotworowych jest wypadkową stanu samej komórki oraz działających na nią czynników zewnętrznych (czynniki wzrostowe, cytokiny, hormony) wytwarzanych przez konkretne mikrośrodowisko. Dodatkowym czynnikiem mającym znaczenie dla przerzutów są zaburzenia w regulacji procesu angiogenezy. Znajomość powiązań między opisywanymi zjawiskami powinna być podstawą do opracowywania nowych terapii i metod diagnostycznych.

\section{Typy komórek i ich zdolność do migracji}

Podstawowe typy komórek w organizmach wielokomórkowych charakteryzuje się ze względu na ich morfologię, polaryzację, obecność połączeń komórka-komórka i ekspresję charakterystycznych markerów. Większość stanowią komórki nabłonkowe (epitelialne), z których wywodzą się nowotwory, nazywane rakami. Komórki nabłonkowe tworzą warstwę lub warstwy, są ściśle zespolone połączeniami międzykomórkowymi kilku rodzajów (połączenia ścisłe — tight junctions, obwódki przylegania - adherent junctions, połączenia szczelinowe - gapjunctions, desmosomy) i wykazują 


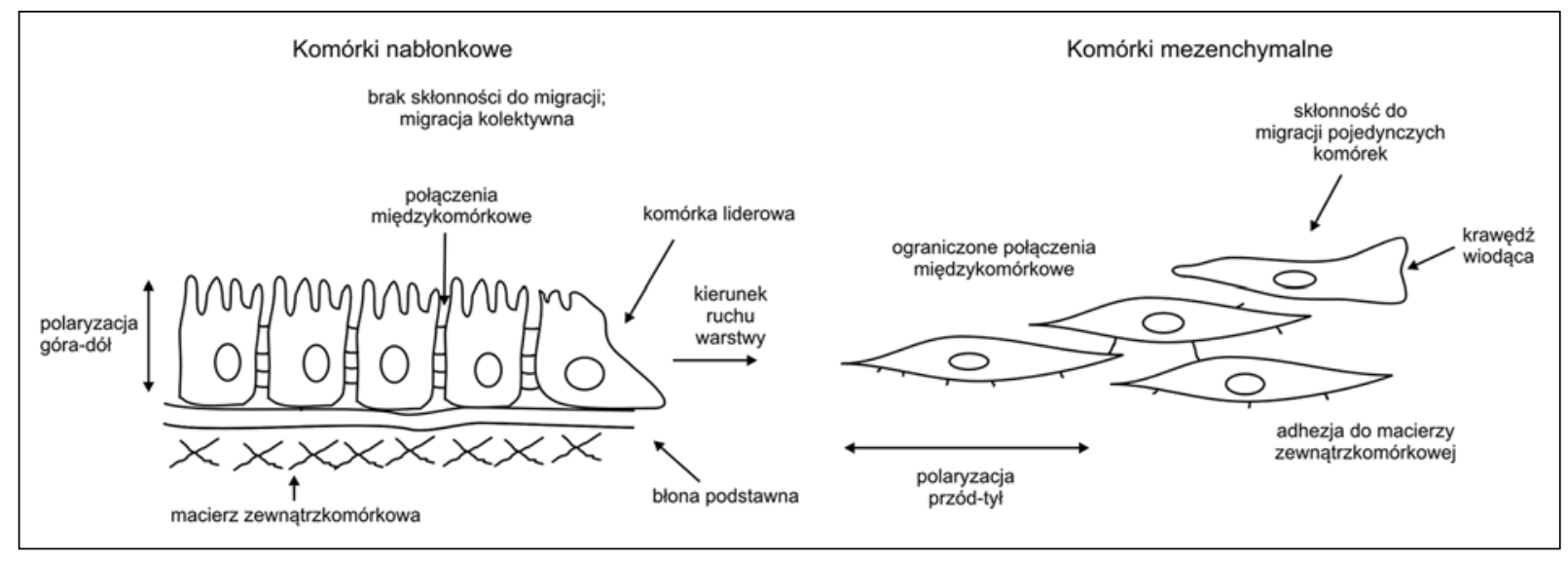

Rycina 1. Komórki nabłonkowe i mezenchymalne różnią się polaryzacją, liczbą połączeń komórka-komórka i skłonnością do migracji. Różnice te mają odbicie w ekspresji określonych markerów, zmieniającej się znacząco w trakcie przejścia epitelialno-mezenchymalnego

polaryzację apikalno-bazalną (góra-dół). Białka występujące w połączeniach komórkowych stanowią markery epitelialne, np. E-kadheryna, występująca w obwódkach przylegania. Komórki tego typu nie są skłonne do migracji, w niektórych przypadkach mogą jednak przemieszczać się jako grupy komórek (migracja kolektywna).

W odróżnieniu od komórek epitelialnych komórki typu mezenchymalnego (np. fibroblasty) mają kształt wrzecionowaty, charakteryzują się dużo mniejszą liczbą połączeń komórka-komórka, ale za to bardzo istotne są ich połączenia z macierzą zewnątrzkomórkową (extracellular matrix, ECM), do których dochodzi za pośrednictwem integryn. Komórki typu mezenchymalnego mają też zdolność do wydzielania enzymów rozkładających macierz zewnątrzkomórkową.

Podstawowe różnice pomiędzy komórkami epitelialnymi i mezenchymalnymi są przedstawione na rycinie 1.

Jeszcze innym typem są okrągłe lub eliptyczne komórki krążące, takie jak limfocyty lub neutrofile.Wykazują one ameboidalny typ migracji, niezależny od połączeń z ECMijej proteolizy.

Komórka określonej tkanki uzyskuje wyżej opisane właściwości podczas rozwoju, ale nie jest to zjawisko nieodwracalne. Nawet w dojrzałym organizmie komórki wykazują pewną plastyczność i zdolność do zmiany fenotypu, do czego najczęściej dochodzi w odpowiedzi na sygnały pochodzące z mikrośrodowiska tworzonego przez otaczające komórki i macierz zewnątrzkomórkową. W ograniczonym zakresie takie zmiany zachodzą fizjologicznie (np. podczas gojenia się ran), ale szczególnie wyraźnie zdolność ta objawia się u komórek po transformacji nowotworowej.

W zależności od typu komórki migracja może odbywać się na kilka sposobów.

\section{Ruch mezenchymalny}

Ten typ migracji jest najlepiej poznany i doczekał się wielu opisów [1, 2, 3]. Dotyczy on migracji pojedynczych komórek. Ruch typu mezenchymalnego jest najbardziej charakterystyczny dla keratynocytów podczas procesów naprawczych, fibroblastów, komórek śródbłonka i komórek mięśni gładkich, a migrujące $w$ ten sposób komórki nowotworowe to w większości komórki wywodzące się z tkanki łącznej, np. w mięsakach, komórki glejaków lub komórki nowotworów z tkanek nabłonkowych, wykazujących silny stopień odróżnicowania [4].

Ruch typu mezenchymalnego opiera się na pięciu cyklicznie powtarzających się etapach, które obejmują: 1) polaryzację i protruzję, czyli tworzenie wypustek 2) tworzenie płytek przylegania (focal adhesions), 3) proteolizę macierzy zewnątrzkomórkowej, 4) kurczenie się włókien aktynomiozynowych, 5) retrakcję krawędzi opóźnionej i przemieszczenie uropodu [5]. Schemat komórki mezenchymalnej wraz z elementami istotnymi dla ruchu przedstawia rycina 2 .

\section{Molekularne podstawy procesu migracji}

Opisane poniżej procesy odnoszą się przede wszystkim do modelu migracji opracowanego dla komórek mezenchymalnych, ale wspomniane zależności i szlaki sygnałowe są istotne dla migracji każdego typu.

Migracja komórki w określonym kierunku jest inicjowana przez gradient czynników wzrostu lub chemokin, a także przez bodźce mechaniczne (rozciąganie komórki), topografię i skład macierzy zewnątrzkomórkowej oraz gradient elektrochemiczny [6]. Na kierunek migracji wpływa również obecność innych komórek i równowaga między siłami odpychania (inhibicja kontaktowa) i przyciągania między komórkami [3]. Ruch komórki jest możliwy dzięki jej polaryzacji na skutek gradientowego rozmieszczenia białek sygnałowych oraz regulujących wewnątrzkomórkowe procesy związane z przebudową cytoszkieletu, tworzeniem wypustek i adhezją. Głównym regulatorem polarności komórki jest przestrzenne zróżnicowanie aktywności małych GTPaz z rodziny RHO, takich jak CDC42, RAC1/2 i RHOA/B. Nadrzędną rolę odgrywa białko CDC42, które jest aktywne w przedniej części migrującej komórki. Zarówno zahamowanie, jak i globalna aktywacja tego regulatora powodują utratę kierunkowości ruchu. CDC42 włącza szlak prowa- 


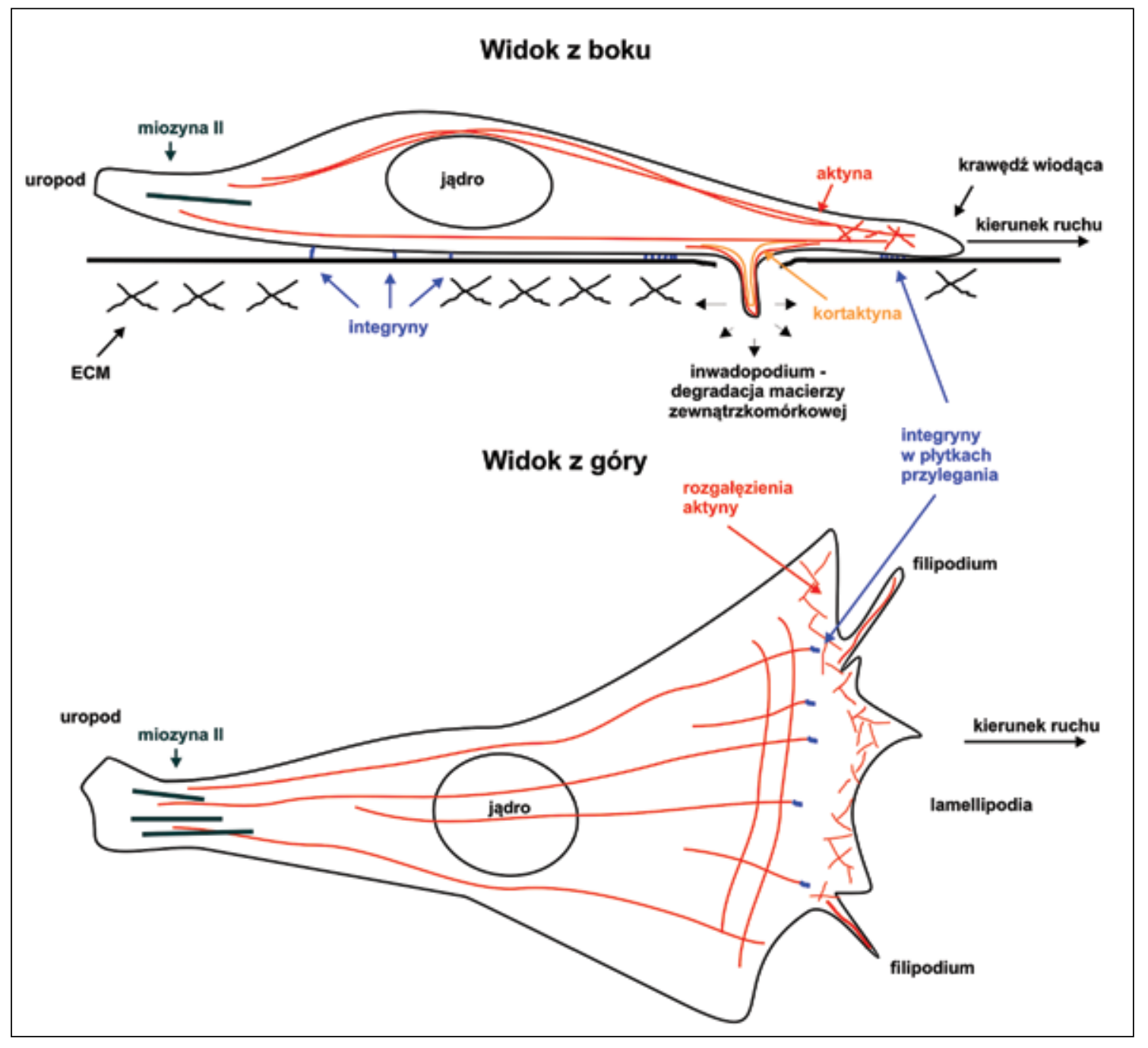

Rycina 2. Polaryzacja, rodzaj wypustek i ruch komórki mezenchymalnej. Do migracji niezbędne jest tworzenie nowych miejsc adhezji do ECM na krawędzi wiodącej, po którym następuje skurcz aktynomiozyny i przemieszczenie uropodu. Dla tego typu poruszania się istotna jest odpowiednia struktura ECM. Lamellipodia i filipodia tworzą się i przemieszczają zgodnie z kierunkiem ruchu komórki, zaś inwadopodia wrastają w macierz zewnątrzkomórkową, degradując ją

dzący do aktywacji RAC1; oba te białka aktywują następnie w sposób zlokalizowany (przy błonie komórkowej) białka rodziny WASP/WAVE. Z kolei WASP/WAVE aktywują czynniki odpowiedzialne za polimeryzację aktyny przy brzegu wiodącym komórki. Umożliwia to tworzenie wypustek, charakterystycznych przede wszystkim dla migracji komórek mezenchymalnych [2].

Zaobserwowano kilka typów wypustek: lammelipodia, filipodia, podosomy/inwadopodia i wybrzuszenia błony komórkowej (membrane blebs). Płaskie, szerokie lammelipodia zawierające rozgałęzione sieci aktyny mają zdolność przemieszczania wiodącego brzegu komórki na duże odległości. Długie, cienkie filipodia zbudowane z równoległych wiązek włókien aktynowych mają znaczenie przy eksploracji otoczenia i są szczególnie istotne dla wzrostu wypustek nerwowych i naczyń krwionośnych. Podosomy i inwadopodia, w przeciwieństwie do dwóch poprzednich typów wypustek, mają zdolność degradacji macierzy zewnątrzkomórkowej dzięki sekrecji proteaz, głównie metaloproteinaz. Polimeryzacja aktyny $w$ lamellipodiach jest zależna od kompleksu ARP2/3 aktywowanego przez WASP/WAVE. Dodatkowe białka wiążące się do monomerów (G-aktyna) i polimerów (F-aktyna) aktyny regulują tempo polimeryzacji i organizację szkieletu aktynowego [2].

Wypustki powstałe na brzegu wiodącym komórki są stabilizowane poprzez powstawanie nowych punktów adhezji komórki do macierzy zewnątrzkomórkowej. Proces ten jest zależny od aktywacji i grupowania integryn [2]. Heterodimeryczne integryny, składające się z łańcucha $\alpha$ i $\beta$, to grupa receptorów transbłonowych, których zewnątrzkomórkowe domeny pozwalają na adhezję do białek macierzy, takich jak kolagen, fibronektyna i laminina. Domeny cytoplazmatyczne integryn wiążą się z licznymi białkami sygnałowymi i adaptorowymi. Białka sygnałowe, takie jak ki- 
naza tyrozynowa FAK (focal adhesion kinase), włączają szlaki regulujące aktywność, m.in. RAC, CDC42 i białka kortaktyny. Białka adaptorowe (m.in. winkulina, talina, $\alpha$-aktynina) odpowiadają za tworzenie połączeń między integrynami a włóknami aktynowymi. Oddziaływania z cytoszkieletem powodują grupowanie integryn i tworzenie struktur adhezyjnych, których dojrzewanie prowadzi do powstawania płytek przylegania.

Aktywność miozyny II regulowana przez małą GTPazę RHO oraz jej efektor - kinazę ROCK (RHO-associated protein kinase) sprzyja formowaniu płytek przylegania [6, 7].W centralnej i tylnej części migrującej komórki włókna aktynowe mają postać grubych włókien aktyny połączonej z miozyną II. Są one kurczliwe, a ich skurcz powoduje przemieszczenie ciała komórki w kierunku brzegu wiodącego. Proces ten jest zależny od stanu ufosforylowania miozyny II i regulowany przez RHO oraz kinazę ROCK. Towarzyszy temu wzrost naprężeń w tylnej części komórki, co skutkuje otwarciem błonowych kanałów jonów wapnia. Napływ $\mathrm{Ca}^{2+}$ powoduje aktywację proteazy kalpainy, która tnie białka odpowiedzialne za adhezję do podłoża. Rozpad struktur adhezyjnych w tylnej części komórki umożliwia przesunięcie tyłu komórki (uropodu) [6]. Następujące po sobie adhezja i destabilizacja punktów przyczepu do podłoża są więc kluczowe dla przemieszczania się komórki.

Ponieważ tworzenie i likwidacja miejsc adhezji wymaga czasu (ok. 10-120 min) ruch mezenchymalny jest mniej dynamiczny niż ruch ameboidalny [8].

\section{Migracja typu ameboidalnego}

Mechanizm migracji ameboidalnej jest jednocześnie najbardziej prymitywnym i najbardziej efektywnym typem przemieszczania się pojedynczej komórki. Swoją nazwę zawdzięcza podobieństwu, w zachowaniu i ruchu, do jednokomórkowego organizmu ameby Dictyostelium discoedium [9]. U wyższych eukariontów ten typ migracji został opisany dla komórek krwi, komórek układu immunologicznego, a także dla niektórych typów nowotworów [10]. Migracja typu ameboidalnego została między innymi stwierdzona w raku piersi, chłoniakach, drobnokomórkowym raku płuca, raku prostaty i czerniaku [11].

Cechami charakterystycznymi dla migracji typu ameboidalnego jest utrata kontaktu z macierzą zewnątrzkomórkową i całkowita utrata polarności komórki. W przeciwieństwie do komórek mezenchymalnych komórki poruszające się tym typem ruchu są okrągłe lub eliptyczne oraz potrafią rosnąć w zawiesinie. Wzmożona kurczliwość cytoszkieletu komórek wykorzystujących ameboidalną strategię inwazyjności, uwarunkowana aktywacją szlaku RHO/ROCK [12], umożliwia im przeciskanie się przez włókna macierzy zewnątrzkomórkowej i dostosowanie kształtu do istniejących przestrzeni [13], a także pozwala na wywarcie siły pozwalającej na przekształcenie macierzy [12]. Ponadto wykazano, iż migracja typu ameboidalnego jest niezależna od degradacji ECM [12], a niska adhezja do jej składników umożliwia komórkom wykorzystującym ten typ ruchu na szybkie przemieszczenie się [14].

\section{Ruch kolektywny}

Kolektywny sposób migracji określa wspólne przemieszczanie się grup komórek, w obrębie których zostały zachowane funkcjonalne połączenia międzykomórkowe, a także oddziaływania z macierzą zewnątrzkomórkową [15]. Ten typ migracji jest istotnym mechanizmem zarówno w rozwoju, w procesach naprawczych, jak i w inwazyjności nowotworów [15]. Zaobserwowano, że w niektórych nowotworach tkanek nabłonkowych komórki migrują kolektywnie i infiltrują do sąsiadujących tkanek bez przejścia epitelialno-mezenchymalnego (epithelial-mesenchymal transition - EMT). Komórki w tym typie migracji tworzą wielokomórkowe łańcuchy, epitelialne płaty lub połączone, spójne zgrupowania kilku-kilkunastu komórek, odłączające się od pierwotnego guza. W zależności od morfologii zgrupowań mogą one migrować kolektywnie jako warstwy, włókna, rurki lub jako klastery [4, 16, 17]. Klastery mogą przedostawać się do krążenia i być przenoszone do innych lokalizacji, tworząc z wysoką częstością odległe przerzuty nowotworowe, charakterystyczne dla guzów słabo odróżnicowanych, podczas gdy inne rodzaje zgrupowań dają przerzuty lokalne [5].

W procesie migracji kolektywnej powstaje funkcjonalna jednostka o asymetrycznym układzie przód-tył, gdzie w części frontalnej znajdują się aktywnie przemieszczające się komórki, natomiast w tylnej — bierne komórki, ciągnięte przez te pierwsze [18]. Na podstawie badań obrazujących ruch tego typu zgrupowań komórek zaobserwowano, iż na krawędzi frontalnej następuje tworzenie się wypustek, natomiast bezpośrednio za krawędzią frontalną tego typu zgrupowania znajduje się obszar tworzenia płytek przylegania. Wprawdzie stwierdzono, że w obrębie zgrupowania komórek może istnieć kilka krawędzi, wzdłuż których powstaje siła ciągnąca, jednak uwarunkowania środowiska powodują, iż tylko jedna jest tą wiodącą, za którą, wskutek sieci powiązań pomiędzy komórkami, podążają pozostałe. Wykazano również, że siły warunkujące mobilność są znacznie wyższe dla klasterów niż dla pojedynczych komórek [19, 20]. W obrębie kolektywnie migrujących komórek istnieją znaczące różnice pomiędzy komórkami liderowymi a tymi, które za nimi podążają. Szczególnie istotne jest skoordynowanie polarności i regulacji aktywności cytoszkieletu w obrębie struktury wielokomórkowej. Istotne znaczenie mają też molekuły adhezyjne, które nie tylko służą utrzymaniu połączeń komórka-komórka i komórka-macierz zewnątrzkomórkowa, ale również wpływają na migrację kolektywną, regulując przepływ sygnałów pomiędzy komórkami. Ważnym aspektem $w$ adhezji międzykomórkowej jest utrzymanie kurczliwości aktynomiozyny na odpowiednio niskim poziomie, 
Tabela I. Zmiany w ekspresji, aktywności i lokalizacji wybranych markerów podczas EMT, według Lee i wsp. [37]

\begin{tabular}{|c|c|c|c|}
\hline Obniżona ekspresja & Podwyższona ekspresja & Wzrost aktywności & Akumulacja w jądrze \\
\hline E-kadheryna & N-kadheryna & ILK & $\beta$-katenina \\
\hline Desmoplakina & Wimentyna & GSK-3 $\beta$ & Smad-2/3 \\
\hline Cytokeratyny & Fibronektyna & Rho & $N F-k \beta$ \\
\hline \multirow[t]{10}{*}{ Okludyna } & Snail1 (Snail) & & Snail1 (Snail) \\
\hline & Snail2 (Slug) & & Snail2 (Slug) \\
\hline & Twist & & Twist \\
\hline & Goosecoid & & \\
\hline & FOXC2 & & \\
\hline & Sox 10 & & \\
\hline & MMP-2 & & \\
\hline & MMP-3 & & \\
\hline & MMP-9 & & \\
\hline & Integryna $\alpha \mathrm{v} \beta 6$ & & \\
\hline
\end{tabular}

tak by zachować połączenia (kohezję) między komórkami w trakcie migracji [17].

Opierając się na modelach mysich, udowodniono, iż klastery krążących komórek nowotworowych (circulating tumor cells - CTC) powstają z oligoklonalnych zgrupowań komórek nowotworowych i nie powstają w wyniku agregacji wewnątrznaczyniowych [21]. Występowanie takich klasterów CTC jest dużo rzadsze niż występowanie pojedynczych krążących komórek nowotworowych (stanowią zaledwie 3\% (TC), natomiast mają 23-50 razy większy potencjał przerzutowania. U pacjentek chorych na raka piersi sekwencjonowanie RNA wykazało, iż czynnikiem różnicującym pojedyncze krążące komórki nowotworowe od krążących klasterów złożonych z tych komórek jest poziom plakoglobiny, która jest istotnym składnikiem połączeń międzykomórkowych. Potwierdzeniem tej zależności są wyniki eksperymentów przeprowadzonych na myszach, gdzie obniżenie ekspresji plakoglobiny przeciwdziałało powstawaniu klasterów CTC i zapobiegało powstawaniu przerzutów do płuc. U pacjentek chorych na raka piersi występowanie klasterów CTC i wysoka ekspresja plakoglobiny w guzie były negatywnym czynnikiem prognostycznym.

Kolektywna migracja jest mechanizmem inwazji i przerzutowania wykorzystywanym przez nowotwory nabłonkowe o dużym stopniu zróżnicowania, np. zrazikowy rak piersi, rak gruczołu krokowego, niedrobnokomórkowy rak płuca, a także w czerniaku i mięśniakomięsaku prążkowanym [18].

\section{Plastyczność komórek nowotworowych i jej wpływ na typ migracji: EMT, MET, MAT}

Komórki nabłonkowe mogą, na drodze tak zwanego przejścia epitelialno-mezenchymalnego (epithelial-mesenchymal transition - EMT), zyskać fenotyp przypominający mezenchymalny. Zjawisko to można podzielić na kilka etapów; są to: integracja sygnałów i zmiany ekspresji określo- nych genów, utrata połączeń międzykomórkowych, zmiana polaryzacji komórki i typu migracji [22]. Fizjologicznie proces EMT zachodzi w czasie implantacji, formowania się zarodka, w gastrulacji, organogenezie oraz podczas gojenia się ran. W warunkach patologicznych EMT obserwuje się podczas włóknienia tkanek oraz w nowotworach. Komórki nowotworowe mogą wykazywać stadia pośrednie pomiędzy fenotypem charakterystycznym dla komórek nabłonkowych i komórek mezenchymalnych, przechodząc niepełne EMT. Przeprogramowanie komórek podczas EMT jest kierowane przez plejotropowe czynniki transkrypcyjne: Snail1, Snail2/ /Slug, ZEB1, ZEB2 i Twist. Dochodzi do rozpadu połączeń między komórkami, między innymi na skutek przełączenia ekspresji kadheryn; E-kadherynę zastępuje N-kadheryna. Komórki tracą polaryzację góra-dół, która jest zastępowana przez polaryzację przód-tył. Przebudowa cytoszkieletu powoduje zmianę morfologii komórki i zwiększoną ruchliwość. Zmienia się profil ekspresji integryn i produkcja metaloproteinaz. Zmieniają się także poziomy ekspresji innych czynników uważanych za markery EMT, z których część wyraźnie zwiększa poziom, innych obniża, a w niektórych przypadkach ma miejsce translokacja do jądra komórkowego (tab. I). Wszystkie te modyfikacje zwiększają potencjał migracyjny i inwazyjny komórek nowotworowych [23].

Proces EMT odgrywa znaczącą rolę podczas inicjacji przerzutu nowotworowego. Podwyższony potencjał migracyjny i inwazyjność pozwala komórkom na przedostanie się do krążenia oraz przeżycie w warunkach krążenia, ponieważ EMT pozwala na uzyskanie odporności na apoptozę, spowodowaną brakiem adhezji (anoikis) [24]. Po przedostaniu się do innej tkanki i wydostaniu się z naczyń komórki nowotworowe są w stanie przejść proces odwrotny do EMT, określany jako przejście mezenchymalno-epitelialne (MET - mesenchymal-epithelial transition). W wyniku tego procesu komórki nowotworowe odzyskują fenotyp charaktery- 
styczny dla komórek nabłonkowych, co jest niezbędne dla formowania się guzów wtórnych [25]. Konieczność przejścia MET dla utworzenia ogniska wtórnego wydaje się najprawdopodobniejszą przyczyną zdecydowanie niższej częstości tworzenia przerzutów przez CTC, stanowiące pojedyncze komórki o fenotypie mezenchymalnym od CTC, będących klasterami komórek epitelialnych, które nie muszą zmieniać fenotypu.

Zarówno EMT, jak i MET wymagają dość rozległych zmian w programie transkrypcyjnym. W odróżnieniu od tego inne przejawy plastyczności komórek nowotworowych prowadzące do zmiany fenotypu i sposobu migracji, takie jak MAT/AMT (MAT — przejście mezenchymalno-ameboidalne, mesenchymal-amoeboid transition, AMT — przejście ameboidalno-mezenchymalne, amoeboid-mesenchymal transition), odbywają się dość raptownie, w odpowiedzi na określone zmiany mikrośrodowiska. Przykładem jest blokowanie rozkładu ECM za pomocą odpowiednich inhibitorów proteaz (przede wszystkim inhibitorów metaloproteaz), co stymuluje komórki do MAT. Proces ten prowadzi do zmiany sposobu poruszania się komórek z mezenchymalnego na ameboidalny [9]. Sugeruje się też, iż możliwa jest bezpośrednia zmiana typu migracji z kolektywnej na ameboidalną. Przykład stanowią komórki czerniaka, w przypadku których taka zmiana została zainicjowana poprzez blokowanie specyficznymi przeciwciałami integryn typu $\beta 1$ [26].

Opisane powyżej procesy stanowią przykłady świadczące o dużej plastyczności i zdolności do kompensacji komórek nowotworowych. W zależności od struktury podłoża oraz sygnałów zewnętrznych docierających do komórek są one w stanie dopasować typ migracji umożliwiający poruszanie się lub optymalizację przemieszczania się komórki w konkretnych warunkach. Zmiany w ilości i sile połączeń typu komórka-komórka oraz komórka-macierz zewnątrzkomórkowa odgrywają kluczową rolę podczas przełączania się komórek pomiędzy różnymi typami migracji, co pozwala im na pokonywanie nowych barier.

\section{Rola macierzy zewnątrzkomórkowej w sterowaniu migracją i inwazją}

Potencjał inwazyjny komórek zależy od ich zdolności do degradowania macierzy zewnątrzkomórkowej (ECM). Jest to głównie cecha komórek mezenchymalnych. Degradacja macierzy jest bezpośrednio związana z wydzielaniem przez komórki zależnych od cynku enzymów proteolitycznych, czyli metaloproteinaz macierzowych. Dwa główne typy metaloproteinaz to białka z grupy MMP (matrix metalloproteinase) i ADAM (A disintegrin and metalloproteinase). Do białek MMP zaliczamy kolagenazy (np. MMP-1), żelatynazy (np. MMP-2, MMP-9), stromielizyny (MMP-3, MMP-10), matrilizyny (np. MMP-7), metaloproteinazy błonowe i inne, nienależące do żadnej z wymienionych grup. W sumie rodzina MMP obejmuje 23 białka, a ADAM — więcej niż 30 białek [27]. Obydwie grupy metaloproteinaz są specyficznie hamowane przez inhibitory TIMP (tissue inhibitors of metaloproteinases).

Degradacja macierzy przeprowadzana przez metaloproteinazy usuwa bariery przestrzenne i pozwala komórkom na przemieszczanie się, do czego dochodzi zarówno w warunkach prawidłowych (np. gojenie ran), jak i patologicznych (np. przerzut nowotworowy). Komórki o wysokim potencjale inwazyjnym są w stanie przedostać się w okolice naczyń (krwionośnych lub limfatycznych) i wniknąć do nich, co umożliwia rozsianie komórek pierwotnego nowotworu i tworzenie przerzutów. Warto jednak dodać, że rozważa się także mechanizm bierny, w którym komórki nie przedostają się do naczyń aktywnie, rozkładając macierz zewnątrzkomórkową i przerywając ciągłość ściany naczyń, ale dostają się tam, odrywając się od masy guza i wnikając do naczyń przez porowate lub uszkodzone ścianki.

Macierz zewnątrzkomórkowa wypełnia przestrzeń między komórkami, spajając tkanki. Jak wykazało wiele ostatnich prac $[28,29]$, macierz zewnątrzkomórkowa nie jest jedynie biernym rusztowaniem dla komórek, ale bardzo dynamiczną strukturą wpływającą na polarność, adhezję, ruch i szlaki sygnałowe. Odpowiedni skład i budowa macierzy jest kluczowym czynnikiem w rozwoju embrionalnym, począwszy od implantacji zarodka [30, 31]. Produkcja, degradacja i reorganizacja ECM są ściśle regulowane, a jej deregulacja i wynikająca z tego dezorganizacja prowadzą do nieprawidłowego funkcjonowania komórek zasiedlających daną niszę i mogą być przyczyną do transformacji nowotworowej.

Macierz zewnątrzkomórkowa jest zbudowana z elementów włóknistych (kolagen, elastyna), proteoglikanów (np. syndekan, dekorin), glikoprotein (np. lamininy, tenascyna C, fibronektyna) i polisacharydów (np. hialuronian), wydzielanych przez różne typy komórek. Macierz zewnątrzkomórkowa występuje w dwóch formach: w postaci błony podstawnej (basement membrane) o charakterze włóknistym, wytwarzanej wspólnie przez komórki nabłonkowe, śródbłonkowe i komórki zrębu, oraz bezpostaciowej substancji podstawowej (interstitial matrix), wytwarzanej głównie przez komórki zrębu [28].

Elementy macierzy stanowią punkty przyczepu dla komórkowych integryn, pozwalając na formowanie się płytek przylegania. Fizyczne własności ECM, takie jak sztywność, porowatość, stopień rozpuszczalności i usytuowanie przestrzenne, wpływają na zdolność komórek do migracji, nadając ECM zdolność do działania na różne sposoby, w zależności od okoliczności: jako bariera, miejsce przyczepu lub szlak do poruszania się. Mogą także stanowić bodziec do zmiany typu migracji, np. macierz odpowiednio miękka jest niekorzystna dla migracji typu mezenchymalnego, ale sprzyja migracji typu ameboidalnego, co może powodować przejście mezenchymalno-ameboidalne. llustruje to, w jaki sposób cechy macierzy indukują istotne zmiany w morfologii i w zachowaniu komórek. 
Fizyczne właściwości ECM nie wyczerpują jednak jej zdolności do oddziaływania na komórki. W macierzy zakotwiczonych jest, w formie nieaktywnej, wiele cząsteczek sygnałowych, i dopiero degradacja macierzy uwalnia aktywne cytokiny. Jest tak np. w przypadku TGF- $\beta$ (transforming growth factor $\beta$ ) i jego latentnej formy wydzielanej do macierzy. TGF- $\beta$ jest syntetyzowany w postaci propeptydu, formuje homodimer i wiąże się z białkiem LAP (latency associated peptide), tworząc kompleks zwany SLC (small latent complex). Po związaniu kolejnego białka (latent TGF- $\beta$-binding protein, LTBP) tworzy się duży kompleks (large latent complex, LLC), który jest wydzielany do ECM. Przed sekrecją część prekursorowa jest odcinana od TGF- $\beta$, ale nie oznacza to jego aktywacji, ponieważ cały kompleks pozostaje niekowalencyjnie związany. Aktywację tego układu może inicjować wiele czynników, takich jak metaloproteinazy, plazmina, trombospondyna, zmiany $\mathrm{w} \mathrm{pH}$, wolne rodniki tlenowe i wiązanie integryn. Aktywny TGF- $\beta$ jest wielofunkcyjnym czynnikiem sygnałowym regulującym proliferację, wzrost, różnicowanie i ruchliwość komórek, a także syntezę składników macierzy zewnątrzkomórkowej. Jest on też jednym z ważniejszych induktorów EMT.

Deregulacja ECM jest często obserwowana w stanach patologicznych. Nadmierna produkcja składników macierzy i zahamowanie ich rozkładu prowadzi do włóknienia tkanek i narządów. W przypadku nowotworów często ulega zmianie architektura i własności fizyczne ECM, np. w raku piersi stwierdzono, że następuje linearna orientacja włókien kolagenu, a ECM potrafi być nawet dziesięć razy sztywniejsza niż w prawidłowej tkance [32]. Sztywność ECM wzmaga wiązanie się do niej komórkowych integryn, co stymuluje odpowiednie szlaki sygnałowe, regulując adhezję, migrację i proliferację komórek. Nieprawidłowa dynamika ECM może zaburzyć ciągłość błony podstawnej i indukować przejście epitelialno-mezenchymalne, podwyższając inwazyjność nowotworu [33]. Sugeruje się także, że ECM ma kluczowe znaczenie dla tworzenia się niszy sprzyjającej transformacji nowotworowej w miejscu pierwotnym, jak i dla tworzenia się niszy metastatycznej w miejscu przerzutu.

Warto zwrócić uwagę na fakt, że za tworzenie się mikrośrodowiska sprzyjającego przerzutowi odpowiadają nie tylko komórki nowotworowe, ale że jest to wypadkową wzajemnego oddziaływania komórek guza, ECM i komórek prawidłowych, takich jak komórki śródbłonka naczyń, fibroblasty zrębu i komórki układu immunologicznego. Fibroblasty związane z nowotworami (cancer-associated fibroblasts - CAF) nie są nowotworowo zmienione, ale są pobudzone do wydzielania cytokin, czynników wzrostowych i proangiogennych [34]. Jednym z takich czynników jest SDF-1 (stromal cell-derived factor-1). Jego funkcjonowanie polega na rekrutacji progenitorowych komórek śródbłonka (endothelial progenitor cells - EPC) w okolice guza, co ma efekt proangiogenny, gdyż mogą się one zróżnicować do związanych z guzem nowotworowym komórek śródbłonka naczyń.

ECM odgrywa ogromną rolę w tworzeniu nowych naczyń krwionośnych i limfatycznych zarówno podczas prawidłowego rozwoju, jak i w trakcie nowotworowej angiogenezy. Produkty degradacji kolagenu (endostatyna, tumstatyna, kanstatyna, aresten i heksastatyna) mają silny wpływ regulatorowy na tworzenie się nowych naczyń [35]. Szczególnie istotna jest działalność metaloproteinaz, prowadząca do przerwania ciągłości błony podstawnej naczynia, a także pozwalająca na wrastanie komórek śródbłonka w obszar macierzy podstawowej podczas rozrostu nowych naczyń. Warto zwrócić uwagę na fakt, że błona podstawna nowych naczyń stymulowanych czynnikami wzrostowymi wydzielanymi przez guz jest o wiele bardziej porowata niż prawidłowa, co ułatwia wnikanie komórek nowotworowych do krążenia. Dysfunkcyjne, nieszczelne naczynia charakterystyczne dla guzów nowotworowych przyciągają fibroblasty i komórki układu immunologicznego, co potęguje zmiany w lokalnym mikrośrodowisku, rozkręcając spiralę zdarzeń prowadzących do przerzutu nowotworowego.

\section{Podsumowanie i wnioski}

Przerzuty są główną przyczyną śmierci pacjentów z chorobą nowotworową [36]. Pojawienie się przerzutu nowotworowego zależy ściśle od potencjału migracyjnego i inwazyjnego komórek guza pierwotnego. Różne typy komórek charakteryzują się odmienną skłonnością do migracji i inwazyjnością, ale ich plastyczność pozwala na zmianę typu w odpowiedzi na odpowiedni sygnał indukujący. W indukowaniu migracji i inwazji oraz w nowotworowej angiogenezie duże znaczenie mają oddziaływania z macierzą zewnątrzkomórkową, a także współdziałanie towarzyszących komórek prawidłowych. Wszystkie te czynniki powinny być w całej swojej złożoności brane pod uwagę przy projektowaniu nowych strategii diagnostycznych czy terapeutycznych, ponieważ skupianie się na jednym elemencie szlaku, np. hamowaniu EMT, metaloproteinaz czy konkretnego typu migracji, może okazać się nieskuteczne ze względu na dużą plastyczność i zdolności adaptacyjne komórek nowotworowych.

\section{Podziękowania}

Publikacja powstała dzięki finansowaniu z projektu NCN 2011/01/B/NZ1/03674.

\section{Lista stosowanych skrótów}

ADAM - A disintegrin and metalloproteinase (dezintegryna i metaloproteinaza, adamalizyny), AMT — amoeboid-mesenchymal transition (przejście ameboidalno-mezenchymalne), CAF — cancer-associated fibroblasts (fibroblasty związane z nowotworami), CTC - circulating tumor cells (krążące komórki nowotworowe), ECM - extracellular 
matrix (macierz zewnątrzkomórkowa), EMT — epithelial-mesenchymal transition (przejście epitelialno-mezenchymalne), EPC - endothelial progenitor cells (progenitorowe komórki śródbłonka), LAP — latency associated peptide (peptyd związany z latencją), LLC — large latent complex (duży kompleks latentny), LTBP - latent TGF- $\beta$-binding protein (latentne białko wiążące TGF- $\beta$ ), MAT - mesenchymal-amoeboid transition (przejście mezenchymalno-ameboidalne), MET - mesenchymal-epithelial transition (przejście mezenchymalno-epitelialne), MMP - matrix metalloproteinases (metaloproteinazy macierzowe), SDF-1 - stromal cell-derived factor-1 (czynnik komórek zrębu 1), SLC — small latent complex (mały kompleks latentny), TGF- $\beta$ - transforming growth factor $\beta$ (transformujący czynnik wzrostowy $\beta$ ), TIMP - tissue inhibitors of metaloproteinases (tkankowe inhibitory metaloproteinaz).

\section{Konflikt interesów: nie zgłoszono}

\section{Dr hab. n. med. Ewa Grzybowska}

Zakład Onkologii Molekularnej i Translacyjnej

Centrum Onkologii - Instytut

im. Marii Skłodowskiej-Curie

ul. Roentgena 5, 02-781 Warszawa

e-mail:ewag@coi.waw.pl

Otrzymano: 1 września 2015 r.

Przyjęto do druku: 29 września 2015 r.

\section{Piśmiennictwo}

1. Ridley AJ. Life at the leading edge. Cell 2011; 145: 1012-1022.

2. Ridley AJ, Schwartz MA, Burrdge $\mathrm{K}$ i wsp. Cell migration: integrating signals from front to back. Science 2003; 302: 1704-1709.

3. Reig G, Pulgar E, Concha ML. Cell migration: from tissue culture to embryos. Development 2014; 141: 1999-2013.

4. Yilmaz M, Christofori G. Mechanisms of motility in metastasizing cells. Mol Cancer Res 2010; 8: 629-642.

5. Friedl $P$, Wolf $K$. Tumour-cell invasion and migration: diversity and escape mechanisms. Nat Rev Cancer 2003; 3: 362-374.

6. Parsons JT, Horwitz AR, Schwartz MA. Cell adhesion: integrating cytoskeletal dynamics and cellular tension. Nat Rev Mol Cell Biol 2010; 11:633-643.

7. Defilippi P, Olivo C, Venturino M i wsp. Actin cytoskeleton organization in response to integrin-mediated adhesion. Microsc Res Tech 1999; 47: 67-78.

8. Pinner S, Sahai E. PDK1 regulates cancer cell motility by antagonising inhibition of ROCK1 by RhoE. Nature Cell Biology 2008; 10: 127-137.

9. Krakhmal NV, Zavyalova MV, Denisov EV i wsp. Cancer invasion: patterns and mechanisms. Acta Naturae 2015; 7: 17-28.

10. Panková K, Rösel $D$, Novotný M i wsp. The molecular mechanisms of transition between mesenchymal and amoeboid invasiveness in tumor cells. Cell Molec Life Sci 2010; 67: 63-71.

11. Van Zijl F, Krupitza G, Mikulits W. Initial steps of metastasis: cell invasion and endothelial transmigration. Mutat Rres 2011; 728: 23-34.
12. Wyckoff JB, Pinner SE, Gschmeissner Si wsp. ROCK- and myosin-dependent matrix deformation enables protease-independent tumor-cell invasion in vivo. Curr Biol 2006; 16: 1515-1523.

13. Wolf $\mathrm{K}$, Mazo I, Leung $\mathrm{H}$ i wsp. Compensation mechanism in tumor cell migration: mesenchymal-amoeboid transition after blocking of pericellular proteolysis. J Cell Biol 2003; 160: 267-277.

14. Sahai E, Marshall CJ. Differing modes of tumour cell invasion have distinct requirements for Rho/ROCK signalling and extracellular proteolysis. Nat Cell Biol 2003; 5: 711-719.

15. FriedI P, Gilmour D. Collective cell migration in morphogenesis, regeneration and cancer. Nat Rev Mol Cell Biol 2009; 10: 445-457.

16. Popow-Woźniak A, Nowak D, Malicka-Błaszkiewicz M. Sposoby migracji komórek nowotworowych. Postepy Biochemii 2009; 55: 113-120.

17. KawauchiT. Cell adhesion and its endocytic regulation in cell migration during neural development and cancer metastasis. Int J Mol Sci 2012; 13: 4564-4590.

18. Friedl P. Prespecification and plasticity: shifting mechanisms of cell migration. Curr Opin Cell Biol 2004; 16: 14-23.

19. Friedl P, Noble PB, Walton PA i wsp. Migration of coordinated cell clusters in mesenchymal and epithelial cancer explants in vitro. Cancer Res 1995; 55: 4557-4560.

20. Kolega J. The movement of cell clusters in vitro: morphology and directionality. J Cell Sci 1981; 49: 15-32.

21. Aceto N, Bardia A, Miyamoto DT i wsp. Circulating tumor cell clusters are oligoclonal precursors of breast cancer metastasis. Cell 2014; 158: 1110-1122.

22. Lamouille S, Xu J, Derynck R. Molecular mechanisms of epithelial-mesenchymal transition. Nat Rev Mol Cell Biol 2014; 15: 178-196.

23. Derynck R, Muthusamy BP, Saeteurn KY. Signaling pathway cooperation in TGF- $\beta$-induced epithelial-mesenchymal transition. Curr Opin Cell Biol 2014; 31: 56-66.

24. Kalluri R, Weinberg RA. The basics of epithelial-mesenchymal transition. J Clin Invest 2009; 119: 1420-1428.

25. Hanahan D, Weinberg RA. Hallmarks of cancer: the next generation Cell 2011; 144: 646-674.

26. Hegerfeldt $Y$, Tusch $M$, Bröcker EB i wsp. Collective cell movement in primary melanoma explants: plasticity of cell-cell interaction, $\beta 1$-integrin function, and migration strategies. Cancer Res 2002; 62: 2125-2130.

27. Visse $\mathrm{R}$, Nagase H. Matrix metalloproteinases and tissue inhibitors of metalloproteinases: structure, function, and biochemistry. Circ Res 2003; 92: 827-839.

28. Lu P, Weaver VM, Werb Z. The extracellular matrix: a dynamic niche in cancer progression. J Cell Biol 2012; 196: 395-406.

29. Kim S-H, Turnbull J, Guimond S. Extracellular matrix and cell signalling: the dynamic cooperation of integrin, proteoglycan and growth factor receptor. Journal Endocrinol 2011; 209: 139-151.

30. Bedzhov I, Zernicka-Goetz M. Self-organizing properties of mouse pluripotent cells initiate morphogenesis upon implantation. Cell 2014 156: 1032-1044.

31. Page-McCaw A, Ewald AJ, Werb Z. Matrix metalloproteinases and the regulation of tissue remodelling. Nat Rev Mol Cell Biol 2007; 8: 221-233.

32. Levental KR, Yu H, Kass L i wsp. Matrix crosslinking forces tumor progression by enhancing integrin signaling. Cell 2009; 139: 891-906.

33. Radisky ES, Radisky DC. Matrix metalloproteinase-induced epithelial-mesenchymal transition in breast cancer.J Mammary Gland Biol and Neoplasia 2010; 15: 201-212.

34. Orimo A, Gupta PB, Sgroi DC i wsp. Stromal fibroblasts present in invasive human breast carcinomas promote tumor growth and angiogenesis through elevated SDF-1/CXCL12 secretion. Cell 2005; 121:335-348.

35. Sudhakar A, Boosani CS. Inhibition of tumor angiogenesis by tumstatin: insights into signaling mechanisms and implications in cancer regression. Pharm Res 2008; 25: 2731-2739.

36. Mehlen P, Puisieux A. Metastasis: a question of life or death. Nat Rev Cancer 2006; 6: 449-458.

37. Lee JM, Dedhar S, Kalluri R, Thompson EW. The epithelial-mesenchymal transition: new insights in signaling, development, and disease. J Cell Biol 2006; 172: 973-981. 